石油などの化石燃料に代わるエネルギー源が世界規模で求めら れています。「地球環境にやさしい」「再生可能な」エネルギー 源であることが重視されるなか、木材や畜産廃棄物などの生物 由来の資源（バイオマス）に注目が集まるようになりました。
ここでは、バイオマスの利点や課題などを概説した Nature 2006 年 12 月 7 日号の論説記事を読んでみましょう。より詳し い事例は、同じ号の Business Feature で読むことができます。

Editorial 語数 : 613 words 分野: 環境・エネルギー

Nature 444, 654 | doi:10.1038/444654a; Published online 6 December 2006

\title{
Green shoots of growth
}

http://www.nature.com/nature/journal/v444/n7120/full/444654a.html

Energy from biomass is an idea whose time has returned.

1. Until the twentieth century, biomass was humanity's principal source of energy, heating our stoves and feeding our draught animals. Even today, roughly $10 \%$ of all our energy comes from biomass - far more than from any other renewable energy source or, for that matter, from nuclear fission.

2. But this use of biomass for energy supply is accompanied by many challenges. For one thing, it is often not all that renewable - the biomass sources that provide firewood to the world's poor, for example, are not being replanted. For another, it is very inefficient: gathering firewood takes a long time. The history of the past couple of centuries has been in large part one of people moving away from biomass as soon as they can afford to do so.

3. Three recent developments have spurred renewed interest in biomass, however. One is the need to reduce greenhouse-gas emissions. The requirement for other external energy inputs during biomass processing means that it often involves some net carbon emissions - but the amount of carbon dioxide given off by burning biomass is the same as that taken from the atmosphere by photosynthesis in the first place. If biomass projects could sequester carbon, either by enriching the soil beneath plantations or by storing any carbon dioxide produced in combustion, they could even be carbon negative - a unique selling point for this energy source.
4. The other two developments are the upward movement in the prices of oil and natural gas, and the related revival of concerns about the security of their supply. Most nations are seeking home-based energy sources that do not rely on political stability in the Middle East or Russia.

5. It seems unlikely that these factors will provide sufficient impetus to propel biomass energy to the very front rank of possible alternatives to fossil fuels. But biomass clearly has a potential role as part of a portfolio of energy sources for the twenty-first century.

6. If that role is to be fulfilled, two things need to happen. Nations have to build regulatory mechanisms that recognize the carbon benefits of technologies such as biomass - through emissions pricing, a carbon tax or a combination of the two. And intensive research needs to be conducted into both the efficient production of biomass and its conversion into useable energy.

7. One focal point for such research should be finding ways to grow biomass quickly and in an easily processed form while minimizing external inputs, such as fertilizer and pesticides. Another is the systems engineering of farms and ecosystems, finding ways to fit biomass projects into and around present land use and possible changes in farming practice.

8. A major attraction of biomass is that it is likely to benefit poorer countries, which tend to be in 
tropical regions where plants grow quickly. There is plenty of scope for more collaboration between developing countries on biomass research and development, both to meet local needs and for export.

9. But this requires consideration of the local and global ecological impact of biomass expansion. Vast tropical monocultures eating away at primary forests - as exemplified by the production of palm oil in Indonesia - will benefit no one, except those who profit from selling the fuel. In effect, such approaches take green subsidies from richer countries, and use them to despoil the tropics.

10. Similar problems afflict existing biomass programmes in the United States, where ethanol refineries often burn fossil fuel and are reliant on subsidized corn monoculture. More innovative approaches would include firing the refineries with agricultural waste, and feeding them with plants of many different species. Biomass energy should be developed energetically, but within the context of appropriate environmental policies, and using approaches that are both sustainable and costeffective.
Topics biomass (バイオマス) とは?

もともとは生態学で使われていた言葉で、「特定地域に生息する生 物の総量、現存量」を意味する。そこから転じて、石油·石炭·天 然ガスなどの化石燃料資源ではない、「原料や燃料として利用でき る生物起源の産業資源」を指すようになった。バイオマスには例 えば、木材や乾燥草本、畜産廃棄物、下水污泥、水草などがある。 バイオマスは、地球規模で大気中の二酸化炭素濃度に影響を与え ない (カーボンニュートラルである) ことと、再生可能であること が大きな特徴である。1990 年代以降、地球温暖化対策や循環型 社会の構築などの観点から注目を集めるようになり、スウェーデン は木質バイオマスの利用に取り組んでいる。日本では、2002 年に 「バイオマス・ニッポン総合戦略」が閣議決定され、地域の特性や 実状に応じたバイオマス利用についての取り組みや情報の共有化 が推進されている。バイオマスは分散しているため、効率よくエネ ルギー化するためにはまだ課題が残る。

\section{Science key words}

3. greenhouse-gas emissions : 「温室効果ガス排出量」 greenhouse gas (温室効果ガス) とは、水蒸気や対流 圏オゾン、二酸化炭素、メタンなどの地表から放射され た赤外線を一部吸収することにより、温室効果（大気圏 の気温上昇) をもたらす気体のこと。

3. photosynthesis : 「光合成」

3. combustion : 燃焼、有機物の酸化」

3. carbon negative : 「炭素収支マイナス」 植物由来の燃料を燃やしたときに放出される二酸化炭素 の量が、元来その植物が光合成によって大気中から取り 込んだ量よりも少ないこと。

7. ecosystems : $\ulcorner$ 生態系」 特定の区域に存在する生物とその非生物的環境をまとめた系。

\section{Words and phrases}

リード whose time has returned : 「再び認められるようになった〜」

1. draught animals : $\ulcorner$ けん引用の動物」 draught は米語では draft とつづられる。

1. for that matter :「それについてさらにいえば」 通常、文章の中で or か and の後に挿入される。

2. For one thing ..., For another ..., : このように 2つの 表現が対になって使われている場合は、それぞれ「第 1 に」第 2 に」などと訳す。

3. spurred : 「拍車をかけた」「弾みをつけた」

3. net carbon emissions : 「炭素排出量の純量」 net は「正味」「純量」の意味で、反意語はgross。 sequester : 「隔離する」「封鎖する」

impetus : 「〜を推し進める力」「〜を行う勢い」

propel : $\lceil$ を推進する」
6. emissions pricing : 「排出量価格 (制度)」

6. carbon tax: 「炭素税」

8. scope : 「余地」「自由」

9. monocultures : 「モノカルチャー、農作物の単一栽培 (一 種類の作物だけを栽培すること)」

9. exemplified by ... : $\ulcorner$ によって例証される」

9. despoil : 「略奪する、収奪する」

接頭辞 de- (分離する) と spoil (もともとの意味である「奪 う」)を組み合わせた単語。

10. afflict : 「苦しめる、悩ます」

10. ethanol refineries: 「エタノール精製工場」

10. sustainable : 「持続可能な」

活動が将来にわたって継続が可能かどうかを示す概念で、環 境問題でよく使用される。エネルギー問題に関していえば、 石油などの化石燃料は unsustainable であるといえる。

10. cost-effective : 「費用対効果が大きい」「経済性に優れた」 
Nature 444, 654 | doi:10.1038/444654a; Published online 6 December 2006

若い芽を大事に育てて地球環境を守ろう

http://www.nature.com/nature/journal/v444/n7120/full/444654a.html

エネルギー源としてのバイオマスが再び注目を集めている。

1. バイオマスは、20 世紀まで人間の主要なエネルギー源で、 ストーブやかまどの燃料となり、荷車を引き、畑を耕す 家畜の餌にもなった。今日でもエネルギー全体の約 10\% がバイオマスに由来している。ほかの再生可能エネルギー 源、具体的には核分裂エネルギーよりもはるかに大きな シェアを占めるエネルギー源なのである。

2. しかし、バイオマスをエネルギー源として利用することに は多くの問題点がある。第 1 に、バイオマスはそれほど再 生可能でないことが多い。例えば、世界の貧困層が薪を得 ているバイオマス源では植林が行われていない。第 2 に、 効率が非常に悪い。薪を集めるには長い時間がかかるのだ。 ほとんどの人間は所得が増えればバイオマスから離れてい くというのが、過去数世紀の人間の歴史だった。

3. それにもかかわらず、最近になって、バイオマスが再び

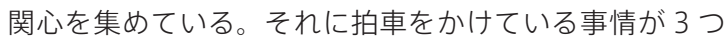
ある。第 1 に、温室効果ガス排出量を減らす必要が生 じていることである。バイオマスを加工する際には、外 部から別のエネルギーを投入する必要があるが、そのた めに炭素の純排出量がいくらか生じることが多い。しか し、バイオマスの燃焼によって発生する二酸化炭素の量 は、バイオマスが光合成によって大気中から吸収した二 酸化炭素の量と同じである。もしバイオマス事業によっ て、農園の地中での二酸化炭素の貯留や、燃焼によって 生じる二酸化炭素の貯蔵によって二酸化炭素を隔離する ことができれば、カーボンネガティブ (炭素収支マイナス) を実現できるかもしれない。これは、バイオマス独自の セールスポイントである。

4. バイオマスが注目される背景にある残りの 2 つの事情と は、原油と天然ガスの価格高騰傾向と、その安定供給へ の懸念の再燃である。ほとんどの国々は、中東や口シア の政情に左右されない国内のエネルギ一源を求めている。

5. これらの要因だけでは、バイオマスエネルギーが化石燃 料の代替エネルギーの有力な候補の座になるだけの力が あるとは思えない。それでもバイオマスには、21 世紀の 一連のエネルギー源の一角を占める潜在性があるのは明 らかである。
6. バイオマスがそのような役割を果たすようになるとした ら、2つのことを実現する必要がある。まず世界各国が、 バイオマスのような技術が炭素排出にもたらす恩恵を前 提とした規制メカニズムを構築する必要がある。その手 段としては、排出量価格制度や炭素税、あるいはその 2 つの組み合わせが考えられる。そして、バイオマスの効 率的な生産とその利用可能エネルギーへの転換に関する 徹底した研究が行われる必要がある。

7. そのような研究において 1 つの重点となるべきなのが、 肥料や農薬など外部からの投入を最小限に抑えつつ、容 易に加工しうる形態のバイオマスを急速に栽培する方法 を見つけることである。もう 1 つ、農場と生態系のシ ステムエンジニアリング研究で、現在の土地利用にバイ オマスプロジェクトを組み入れ、農業の変革にバイオマ スを生かす方法を発見することである。

8. バイオマスの大きな利点は、植物の成長が旺盛な熱帯地 方に点在する貧困国が恩恵を受ける可能性が高いことで ある。バイオマスの研究開発において開発途上国間の協 力関係を強化して、地元のニーズに対応し、輸出品とし ても利用する余地は十分にある。

9. しかしそのためには、バイオマスの生産拡大によって、栽 培地域と全世界にどのような生態学的影響が及ぶのかを検 討する必要がある。インドネシアでのパーム油生産にみら れるように、熱帯のモノカルチャーが原生林を食いつぶし ていくということでは、パーム油の取引で利益を得る者以 外は誰も恩恵を受けないということになってしまう。これ では、富裕国から環境保護助成金を奪い取り、それを熱帯 地域からの収奪に使うだけで終わってしまうのだ。

10. 現在米国で実施されているバイオマス事業にも同じよう な問題点がある。多くのエタノール精製工場では化石燃 料を使い、政府から助成されたトウモロコシのモノカル チャーに依存しているのである。より革新的な手法は、 精製工場で農業廃棄物を燃料とし、さまざまな種類の植 物バイオマスを投入することである。バイオマスエネル ギーの開発は精力的に行われるべきだが、適切な環境政 策に組み込まれ、持続可能でコスト効率のよい方法を使 うべきなのである。 